> Gi respons på artikler gjennom artiklenes kommentarfelt på tidsskriftet.no.

Innleggene publiseres fortløpende på Tidsskriftets nettside og et utvalg

av innleggene publiseres også i papirutgaven i spalten «Brev til redaktøren».

Redaksjonen forbeholder seg retten til å foreta redaksjonelle endringer.

Forfattere av vitenskapelige artikler har tilsvarsrett, jf. Vancouver-gruppens regler.

\section{Re: En varslet katastrofe}

Mons Lies leder i tidsskriftet nr. 7-8/2017 om utviklingen ved Oslo universitetssykehus slutter jeg meg til (1). Jeg har selv ved flere anledninger forsøkt å varsle, men uten respons (2-4). Jeg kan supplere Lies varsel med et poeng til.

Statistisk sentralbyrå oppgir at det i 2015 bodde 658390 innbyggere i Oslo og 594799 i Akershus. Ved fremskrivning har de kommet til at i 2040 vil Oslo ha 854000 og Akershus 768 000, dvs. en samlet økning på knapt 370000 innbyggere (5). Hva er det så ledelsen i Oslo universitetssykehus og deres overordnede organ Helse Sør-Øst har planlagt for? Ingen økning i lokalsykehusfunksjon for Lovisenberg og Diakonhjemmet, opprette lokalsykehusfunksjon for 70 000-80 000 på Rikshospitalet, bygge nytt Aker sykehus med kapasitet for cirka 110000 og legge ned Ullevål sykehus, som i 2015 var lokalsykehus for knapt 220000 innbyggere. Det betyr at den planlagte utbyggingen snaut nok har kapasitet til det Ullevål dekket i 2015. Ettersom Akershus universitetssykehus allerede er sprengt, vil det uten revisjon av planene være cirka 370000 innbyggere som står uten lokalsykehus i 2040. Kreftregisteret sendte i september 2016 ut en rapport som viste at antallet krefttilfeller vil øke med nær $40 \%$ for menn og $27 \%$ for kvinner frem mot 2030 (6). Helse Sør-Øst planlegger et nytt kreftbygg på Radiumhospitalet, men det gir ikke økt kapasitet. Hva man skal gjøre for å møte økningen, og for å ta hånd om de pasientene som $\mathrm{i}$ dag behandles ved Kreftsenteret på Ullevål, har man ingen planer for.

Begrunnelsen for å legge ned Ullevål sykehus er at bygningsmassen er gammel og nedslitt. Men de underslår at det finnes nær $100000 \mathrm{~m}^{2}$ nyere, godt funksjonelle bygninger, med blant annet et akuttbygg fra 2014 og kreftsenter fra 2006. Med et nytt klinikkbygg nord for Midtblokken vil Ullevål være et godt lokalsykehus for flere enn de innbyggerne det dekker i dag. Utgifter til dette blir neppe vesentlig større enn kostnadene ved å vedlikeholde de $115 \mathrm{og}$ 102 år gamle byggene som i dag brukes til sengeposter og poliklinikker i de 10-15 år det vil ta før planlagte bygg på Gaustad og Aker står ferdig . Med utvidelse av Kreftsenteret nordover kan man øke kapasiteten for kreft. Beholder man Ullevål, vil det ikke være nødvendig å investere i et nytt stort akuttmottak på Rikshospitalet. Det har man allerede på Ullevål.

Men kjernepunktet i innlegget er å vise at Helse Sør-Øst ikke har forsvarlige planer for å ivareta behovet for sykehustjenester $i$ årene frem mot 2030-40. Og når dette nivået svikter, er det helse- og omsorgsministeren som må ta ansvaret. Hvis han ikke gjør det, må den politiske opposisjonen stille spørsmål om hvordan dette skal løses.

\section{Rolf Kåresen}

Rolf.karesen@medisin.uio.no

Rolf Kåresen er dr. med., professor emeritus, tidligere overlege, avdelingsoverlege og sjeflege ved Ullevål universitetssykehus.

Oppgitte interessekonflikter: Forfatter har deltatt i planlegging og gjennomføring av utbygginger på sykehuset i årenen 1992-2007.

\section{Litteratur}

1. Lie M. En varslet katastrofe. Tidsskr Nor Legeforen 2017; 137: 504. 2. Kåresen R. Mot organisatorisk kaos? Tidsskr Nor Legeforen 2010; 130: 2453

Kåresen R. Å legge ned Ullevål sykehus løser ikke problemet. Aftenposten 2016 http://eavis.aftenposten.no/aftenposten/20718/61/?query=ullev\%C3\%A5l\%20 sykehus $\% 20$ og\%20rolf\%20k\%C3\%A5resen (7.4.2017)

4. Kåresen R. Ullevål sykehus kommer til å trenges. Klassekampen 2016; http://www.klassekampen.no/section/search?text=rolf+k\%E5resen
5. Leknes S. Regionale befolkningsframskrivinger 2016-2040: Flytteforutsetninger og resultater. Økonomiske analyser 3/2016. Statistisk sentralbyrå. https://www.ssb.no/befolkning/artikler-og-publikasjoner/_attachment/ 270395? ts $=1556 \mathrm{~d} 68 \mathrm{ed} 68$ (7.4.2017)

6. Kreftregisteret. Stor økning i krefttilfeller fram mot 2030 https://www.kreftregisteret.no/Generelt/Nyheter/Stor-okning-i-krefttilfellerfram-mot-2030/ (7.4.2017).

\section{Re: Fosteret som prøvestein og brekkstang}

Helse- og omsorgsdepartementet godkjente 1. mars 2017 ikkeinvasiv prenatal testing (NIPT) for påvisning av trisomi 13, $18 \mathrm{og}$ 21 etter bioteknologiloven $\S 4-2$. Bjørn Hofmann \& Ketil Slagstad uttrykker sin uenighet med Helsedirektoratet (1). De hevder at anbefalingen er svakt begrunnet og dårlig gjennomtenkt, og at den gir uttrykk for en kalkulert strategi for å sementere fostermedisinerne sin rolle i den fremtidige svangerskapsomsorgen.

Metoden ble godkjent innenfor gjeldende vilkår for fosterdiagnostikk som alternativ til morkakeprøve eller fostervannsprøve. Metoden er bare godkjent innen fosterdiagnostikk for gravide som først har tatt kombinert ultralydundersøkelse og blodprøver, og som har fått påvist høy risiko (veiledende 1:250 eller høyere) for trisomi hos foster. Vedtaket er i samsvar med Helsedirektoratet sin anbefaling.

Hvis målet med fosterdiagnostikk i første trimester bare er å oppdage fleste mulig trisomier, kan man forstå kritikken mot Helsedirektoratets anbefaling, men fosterdiagnostikk er så mye mer. I henhold til lov om bioteknologi er formålet med fosterdiagnostikk å oppdage sykdom, skade eller utviklingsavvik hos fosteret.

Fosterdiagnostikk og fostermedisin tilbys for at flest mulig fostre kan fødes levedyktig og uten sykdom eller skade som kunne vært forhindret. I Norge er det bare kvinner som er over 38 år eller har spesielle risikofaktorer som tilbys fosterdiagnostikk i første trimester. Spesielle risikofaktorer omfatter gravide der kvinnen selv eller hennes partner tidligere har fått et barn eller foster med alvorlig sykdom eller utviklingsavvik, har økt risiko for alvorlig sykdom hos fosteret, bruker medisiner som kan skade fosteret og gravide som er i en vanskelig livssituasjon og mener at de ikke vil klare den ekstra belastningen et sykt eller funksjonshemmet barn kan medføre. Det må være en målsetting å gi disse kvinnene så god informasjon om svangerskapet som mulig istedenfor ensidig å fokusere på trisomier. Før det utføres fosterdiagnostikk skal kvinnen få informasjon om at undersøkelsen er frivillig, om risiko ved prøvetaking og hvilke konsekvenser diagnostikken kan få for henne selv og for fosteret eller barnet.

Nakkeoppklaringen skyldes ødem i nakken hos fosteret, og stor nakkeoppklaring er assosiert med trisomier. Økt nakkoppklaring er ikke bare assosiert med trisomier, men er også forbundet med fosteravvik. Alvorlige fosteravvik som akrani (anencephalus), skjelettdysplasier, megacyste (stor urinblære pga. av urethraklaffer) og omphalocele (bukveggsbrokk) kan med stor sikkerhet oppdages i første trimester.

Det er ikke urimelig at fostermedisinerne har en sentral rolle i oppfølging av risikosvangerskap på tilsvarende måte som kardiologer har en sentral rolle i oppfølging av pasienter med hjertesykdom. Vi støtter Helsedirektoratets forslag og Helse- og omsorgsdepartementets vedtak. Hovedformålet med fosterdiagnostikk 